\title{
The Way of Indonesia to Attract and Protect Foreign Investment
}

\author{
Hasjim Muzadi \\ Mas'ud Machfudz
}

Dalam hubungan ekonomi dunia, sebuah bangsa bisa menarik investasi asing hanya jika dia mempunyai prasyarat yang dibutuhkan, di antaranya dalam hal bagaimana mekanisme pasar berjalan (antara lain dalam perbankan, ketenagakerjaan serta penyelsaian konflik). Juga, faktorlain semacam kepastian dalam aspek hukum, politik dan keamanan. Berkenaan dengan kondisi Indonesia saat ini khususnya dengan adanya pemilihan umum yang berartijuga pergantian kekuasaan, para investor masih wait and see, apakah situasi politik menunjukkan tanda-tanda baik ataukan buruk, apakah pemilihan umum akan bisa memberikan bangsa ini seorang pemimpin baru dengan semangat baru dan daya tarik baru, sehingga bangsa ini bisa mengatasi berbagai problem seperti terorisme, ketidakpastian hukum, kerusakan moral-khususnya dalam perbankan-yang telah menyisakan kesan buruk bagi tercapainya kesempatan yang lebih baik dan upaya penciptaan iklim internasional yang lebih baik tanpa harus kehilangan kedaulatan sebagai sebuah bangsa.

A $s$ the largest archipelagic country in the world, Indonesia is located on the cross of two great continents (Asia and Australia) and two Oceans (Indian and Pacific). Beside this strategic place, Indonesia also offers some comparative advantages to investors who invest their funds in this country.

The total of Indonesia area is 1,919,440 sq $\mathrm{km}$ consisting water area around 93,000 sq $\mathrm{km}$ and $1,826,440 \mathrm{sq} \mathrm{km}$ of land. Its territory is divided into 30 provinces and 416 cities/districts. Most of people live in Java Island and $45 \%$ of total population in 1998 is Javanese, Sundanese $14 \%$, Maduranese $7,5 \%$, Coastal Malays 7,5\%, and others $26 \%$. Moreover $88 \%$ of total population are Muslims, Protestant 5\%, Roman Chatolic $3 \%$, Hindu $2 \%$, Budhist $1 \%$, and others $1 \%$. Beside the huge diversified ethnic group and religion, Indonesia also has many differences in cultures, native languages, and dialects.

The country also has the huge and diversified natural resources, such as forestry, fisheries, agricultures, plantations, mining, oil and gas. Indonesia with an estimated population of 212 millions in 2002 , is the fourth most populous country in the world, and also provides a huge potential market as well as the competitive work force.

This paper introduces the highlights of current Indonesia Economy focusing in foreign investment, in the other part of this paper we would like to also giving the perspective of macro and micro economic. We also discuss the facts that most of Indonesian Muslims are moderate rather than the negative unproved common perspective of Indonesian Muslims environment and situa- 
tion, especially post the Bali and Marriots blasts.

\section{Macroeconomic Indicators}

The Indonesia macroeconomic indicators have made substantial progress since the crisis. Table 1 presents the selected macroeconomic indicators during 19982002. The economy created positive growths of real GDP during 1999-2002. However, the economic growth was only $3.7 \%$ in 2002 and it had unbalanced structure. The economic growths particularly depended upon consumption since the financial crisis of 1997 . while the investments and exports (which initially predicted to improve in 2002) actually contracted in the same period. The contracted investments had significantly implication on reduced imports, especially imports of raw materials and capital goods. On the labor front, the moderate economic growth of $3.7 \%$ is estimated to absorb only 0.8 million workers, out of 1.7 million new entrants into the labor force last year. Consequently, open unemployment reached 9.1 million, representing an (open) unemployment rate of $9.1 \%$.

On the output side, all economic sectors expanded in 2002 with transportation and communication as well as electricity, gas and clean water recording the highest growth of $7.8 \%$ and $6.2 \%$ respectively. Despite making the largest contribution to overall growth, manufacturing's pace of expansion virtually unchanged in 2002 to $4.0 \%$ from $4.1 \%$ in 2001 . The continuing financial, ownership, and business services strengthened sectors also contributed to economic growth by $5.6 \%$ of increases.

On the expenditure side, consumption grew appreciably, despite its earlier prediction to slowdown over the 2001. Private consumption grew by $4.7 \%$ during 2002 , while government consumption grew by $12.8 \%$. Investment, which had been predicted to improve in the second half of 2002, turned out to be unfavorable. For the year as a whole, it contracted by $0.2 \%$, much lower than in $2001(7.7 \%)$ and in $2000(13.8 \%)$. Lower investment was consistent with weaker construction activity and lower imports of capital goods (such as machinery and equipment). On the external side, exports dropped by $1.2 \%$, much lower than the growth of $1.9 \%$ in the previous year, while imports also declined, by $8.3 \%$.

Low investment and exports are inherent in the high investment risk and deteriorating competitiveness of Indonesian economy due to the structural problems. In addition, investment and exports were hurt by the weak global economy, more intense global and regional competition and on going protectionism in several countries.

On the fiscal side, implementation of the government budget during 2002 reflected financial consolidation to ensure mediumterm fiscal sustainability. However, the deficit narrowed much more than expected, mainly due to very low realizations of development spending. The fiscal deficit for 2002 is estimated at $1.7 \%$ of GDP, lower than the budget target of $2.5 \%$. On the revenue side, the tax ratio reached only $12.7 \%$ of GDP.

On the external side, Indonesia's overall balance of payments (BOP) improved, due to a wider current account surplus and a narrower capital account deficit. The current account surplus reached US\$. 7,262 billion or 3,9\% of GDP while the capital account deficit was around US $\$-3,592$ billion or $1,9 \%$ of GDP. The improved current account was mainly due to better export performance; in the case of the capital account, it was mainly due to successful foreign debt restructuring. 
In monetary side, the exchange rate strengthened significantly with relatively little volatility while base money was under control and below its indicative target, and money supply (M2) increased, albeit at a slower pace than in 2001. The inflation rate and interest rates dropped significantly from crisis level, from $77,6 \%$ in 1998 became $10,0 \%$ in 2002 . Hence, money market and deposit rates also declined to be $13.5 \%$ and $15.5 \%$, respectively.

However, crisis still leaved behind its bad effects to Indonesian economy, especially for unemployment and fiscal conditions. After little declining to be $6.1 \%$ in 2000 , open unemployment rate increased again in 2001 and 2002 , or $8.1 \%$ and $9.1 \%$, respectively. To finance the recapitulation of banks, the Indonesia's government had to create domestic debt via issuing obligations as well as external debt. The total outstanding external debt in the end of period 2002 was US $\$ 131,343$ million. The $54.3 \%$ of the total debt was public debt and $45,7 \%$ remainder to private. Moreover, The crisis also caused sharp increases in the severity of poverty. One estimate shows that 1996 and 1999 the number of people falling below $65 \%$ of the poverty line increased by $73 \%$ and $63 \%$ in urban and rural areas respectively (Indonesia Human Development Report, 2001).

In general, the good performances are quite favorably as indicated by more stable macroeconomic conditions. Consistent monetary, fiscal, and real sector policies, supported by progress in several aspects of economic restructuring, helped to achieve economic and monetary stability throughout 2002. Stable monetary conditions in 2002 strengthened the economic climate as reflected in improved expectations of the business community towards economic recovery.

\section{Foreign Investment Environment}

Table 2 presents the trend of domestic and foreign investment approvals in Indonesia during 1967-June 2003. The total projects of foreign investment approvals 1967-2003 were 12,534 projects with the investment value of US\$. 262,875 million. The significant increased foreign investment approvals were happed in 1994. In this year the total approved projects itself were 782 with the investment value of US $\$ 39,891.6 \mathrm{mil}-$ lion. However, the foreign investment approval declined slightly in value after the crisis although the number of projects increases.

In recently, the total projects of foreign investment approvals during January-June 2003 were 497 projects with the value of US\$. 4,373.1 million. There were also 139 approvals for extension of existing foreign companies with the investment value of US\$. 584.8 million, (see Table 3 and 4). These data figure-out that in spite of the foreign investors enter the green fields' activities (new investment), most importantly the existing companies still have the opportunities to develop and expand their business activities in Indonesia.

However, the diversification seemed be happen from secondary to tertiary sector. During the period of January-June 2003 the popular sector where investors interested in, were Trading \& Repair (192 projects), Other Services (73 Projects), Metal, Machinery \& Electronic Industry (50 projects), and Hotel and Restaurant ( 31 projects).

The diversification was not only in sector but also in location. Table 5 presents the foreign investment approvals by location. Java Island was still the favor place of foreign investment during 1998-2002 with Jakarta as the leading place. But it seemed that there was anew trend of diversification of places to Kalimantan and Sumatra Is- 
lands. In Sumatra, Riau pervaded about $78 \%$ of total projects in the Island with the investment value around US\$. 1,153 million while in Kalimantan, - East Kalimantan absorbed ábout $86 \%$ of total projects with the value around US\$. 2,192.7 million.

Asian investors, especially from Japan, South Korea, and other ASEAN countries still dominated the investment projects in Indonesia as explained in Table 6 . Even though, the potential investors also came from Europe, America, and Africa. Investors from Mauritius of Africa for example, approved investment values bigger than Japanese investor during January-June 2003.

During 1990-2001, there was 1,893 billion value of foreign direct investment (FDI) from Japanese investors to Indonesia. It was $16.4 \%$ of total Japanese FDI to Asia or $2.9 \%$ of total Japanese FDI around the world The FDI was allocated $52.1 \%$ to manufacturing sectors and $47.3 \%$ to non manufacturing sectors.

From the survey of Japan Bank for International Cooperation to Japanese investors in 2002, Indonesia was still included in Ten Most Promising Economies of Japanese FDI in 1995-2001 for medium term ( 3 years) as well as long-term (10 years). It means that Indonesia was still an attracted host country for Japanese foreign direct investment even the economy was crisis during 1997-1998. The main reason for this, comparing to other Asia countries was because of relatively lower business cost.

\section{The Problem and Challenges of Foreign Investment}

According to Bank Indonesia views, Indonesia's economy in general and especially foreign investment prospects for years ahead will be strongly affected by a number of risks and uncertainties, both domestic and foreign (Bank Indonesia, 2003). The main factors in this regard can be explained as follows.

1. The external side, although the overall world economy is forecast to improve, there is also greater uncertainty. World economic growth in years ahead is largely contributed from within the Asian region. At the same time, growth in most industrialized countries (such as the US and Japan) is forecast to be moderate. Prolonged political tension in the Middle East will deteriorate global economic growth and have a large impact on world trade. This in turn will affect global investment climate and also worsen investors' perception on Indonesia's economic prospect.

2. The side of investor and foreign trade partners, negative perceptions of the Indonesian economy could intensity. This is based on various socio-political and security issues which deteriorated following the Bali and Marriotts incidents. Also, international confidence will require a "war premium" on Indonesian trading activities. The premium will raise transaction costs of foreign trading partners and deepen the concern about investing in Indonesia.

3. On the internal side, political and security conditions will be especially important in advance of the 2004 General Election. Despite continued improvements, developments in this regard contain uncertainties that could raise political instability. If these rise excessively, in the short-term it will weaken key variables, such as the exchange rate and demand for currency. This will also harm the real sector because of weakening consumer confidence and further deterioration in the investment climate. 
4. On-going labor conflicts (characterized by strikes) could disrupt social harmony and raise business uncertainty. This issue has the potential to significantly raise the number of layoffs, and further reduce the interest of foreign parties in trading and investing in Indonesia. Furthermore, higher wages as a solution to labor conflicts will lower the competitiveness of Indonesia products, if they are not accompanied by higher productivity.

5. Various unsatisfactory processes and settlements of several large legal cases have hurt public perceptions of the supremacy of law in Indonesia. These cases damage global business confidence in the domestic investment climate, further reducing investor interest in Indonesia. Also, this reduces the government's credibility in its commitment to implementing good governance.

6. Bank intermediation is proceeding more slowly than expected. Although credit expansion did improve in 2002, growth was still far below the needs of the real sector. The banks are reluctant to extend credit as reflected in the rigidity of credit rates in the face of lower SBI rates, and limited long-term financing is a barrier to investment as a source of growth.

7. In line with ending the IMF program at the end of 2003, an exit strategy should be carefully considered. On the one hand, a successful exit from the IMF program could maintain international confidence and re-establish independence in economic policy-making. On the other hand, failure to maintain discipline in fiscal and balance of payments issues without the IMF will worsen prospects for the Indonesian economy.
8. The problems also rise from decentralization processes. The problems are commonly the increasing legislations unpredictable and many of them precisely impede investment progress. Hence, decentralization processes also hamper the progress of privatization of state owned enterprises.

Political and social instability were the most important problem to be faced by Indonesia on foreign investors' view, especially Japanese investors (see Table 9). However, it needs to stress that foreign investor should realize that the crisis might be the main cause of social uncertainty in 1997-1998. Moreover, Indonesia is doing the processes of reformation in political, economic, and social sectors and social uncertainty is the cost of it. However, the Indonesian political and social instabilities seem be temporary situation.

In reviewing social conflicts in Indonesia during 1990-2001, Tadjoeddin (2002) has presented informative classification of social conflicts by the area of conflicts (see Table 11). The high conflicts were happened only in 3 provinces (Maluku, central Kalimantan, and N. Aceh Darussalam) of the total 30 provinces in Indonesia and the communal high conflicts were happened only in 8 cities/districts, compared to 294 cities/districts of total in Indonesia. In present day, only Aceh is still in conflicts because of separatism while the other provinces have been recovered.

What the massage in here is that the potential investors from overseas should change their perspective of social instability from national to local point of view. Indonesia is a large country and more than 17.000 islands. The major islands are Sumatra, Java, Kalimantan, Sulawesi, and Papua. Every social conflicts is happened in one cities or districts, it is hard to spread to other 
location because of long distance (consider Figure 1 to see the locations of conflicts) and effectiveness of sterilized acts or at least localization of the conflict by the police/security departments.

In political sector review, the uncertainty was grown up from during the campaign processes in General Election 1999. it also rose from amendment of Constitution debates and during the processing of Abdurrahaman Wahid (former president) impeachment. The political uncertainty in year to go will be also conducting to General Election of Representative and president. However, the uncertainty will increase if.and if only there will be weak law enforcement in the future. Moreover, the uncertainty also became from the weakness of law enforcement and security problems, especially bombing incidents.

\section{The Key of Attractiveness and Protection of Foreign Investment}

To avoid or reduce the effected problems to investment environment in Indonesia, there are several ways to attract and protect foreign investment. They can be explained as follows.

1. The initiatives directly to investment environment can be seen in Indonesia Investment Board website at www.bkpm.go.id. The initiatives included legal aspects, taxation and losses, incentives, bonded zones, land and building, relevance international agreements (include: Investment Guarantee and Protection Agreement, Intellectual Property Rights/ Patent, trademark, and copyright), immigration condition, environment protection, business entrance.

In line of such environments, it can be summarized as follows.
A huge potential of natural resources and market șize;

- Relatively less cost of investing projects comparing to other countries regionally;

- More liberalized economy due to free and fair competition with good climate of taxation, and incentives;

- High care of protection to foreign investment. In most cases, these guarantees cover compensation in case of nationalization or expropriation, damages or losses caused by incidents of war, revolution or insurrection and payments for any approved remittance pursuant to the investment in case of non-convertibility of currency of the host country. To provide security for foreign investment, the Government of Indonesia concludes Investment Guarantee Agreement (IGA) with ASEAN governments. Beside, Indonesia signed bilaterally the Investment Promotion and Protection Agreements with 55 countries and Avoiding Double Taxation Agreements with 50 countries (see Table 12).

- To create a favorable international investment climate, Indonesia has also signed multilateral agree- ments thereby promoting foreign direct investment in Indonesia. Indonesia is now a member of the Multilateral Investment Guarantee Agency (MIGA), which will protect investment against various political risks. To deal with foreign investment disputes, Indonesia has become a signatory member of the International Center on Settle- 
ment of Investment Disputes (ICSID).

2. Approve Macroeconomic Stabilization

a. More stabilized banking system. The stabilization in banking system was the priority of government since the crisis. The policies for this sector ware purposed to make stronger banking system and to avoid bank run (rust) as well as bank panic. Continuing the banking policy pursued last year, in 2002 Bank Indonesia focused on three programs, namely bank rehabilitation, banking resilience, and bank intermediation. On the banking front, policies will be aimed at rebuilding the banking system and strengthening banks' resilience by emphasizing riskbased supervision. To strengthen the Indonesian banking system, Bank Indonesia is developing the Architecture of the Indonesian Banking System, which will be completed in 2003. To enhance the role of Bank Indonesia in maintaining financial system stability, Bank Indonesia is preparing a Blue Print for Financial System Stability Covering: surveillance and monitoring of financial system stability; crisis resolution; and the organizational framework. In addition, Bank Indonesia continues to promote the recovery of bank intermediation (Bank Indonesia, 2003).

b. Monetary policy will be aimed at absorbing banks' excess liquidity and lowering interest rates to send conducive signals and improve the supply side of the real sector. Operationally, the strategy of monetary policy was to optimize the available monetary instruments; open market operations (OMO) and foreign exchange intervention/ sterilization were used to absorb excess liquidity in the context of a declining trend in $\mathrm{SBI}$ rates. This strategy was undertaken as long as it did not induce inflationary pressures that might eventually cause inflation to exceed Bank Indonesia's target.

c. Fiscal policy will be aimed at stimulating the real sector to improve economic activity, especially in small-medium enterprises. Hence, the fiscal policy will also continue to reduce budget deficit. The management of public debts, domestic as well as external debts also include in consideration.

3. Reformation of laws as well as the staffs is aimed at guarantying the law enforcement. The significant issued-law recently is The Law of Anti Terrorism. The People Representative Board or Dewan Perwakilan Rakyat (DPR) also is processing to build the Constitution Court and elect the Constitution Judges.

\section{Is it Necessary Afraid of Indone- sian Muslims?}

Recently, it is necessary to determine whether the Muslims in Indonesia are fundamentalists or not. Moreover, if there are fundamentalists in Indonesia, do they tend to be destructors or terrorists? indeed, there is no easy way of defining Indonesian Muslim. However, it still can divide the Muslims by his/her perspectives about Western ideas particularly about democracy, liberalism, 
human rights, equality, rule of law, free markets, and separation between religion and state. As a common perspective (indeed in western), the Muslim who support these ideas, in some how could be called as moderates and other side, which reject would be called fundamentalists.

However, the most westerners, with shallow or high knowledge of Islam as religion believe that Islam in term of religion cannot be suitable to those ideas. One was that of Harvard political scientist and U.S. State Department adviser Samuel Huntington. In 1993 Huntington presented a deeply relativistic reassessment of democracy's future. We are mistaken to assume that all societies can develop democratic institutions, Huntington argued, because the principles of democracy are incompatible with the cultures of many. The list of alleged incompatibilities underscored the enormity of the problem. "Western ideas have little resonance in Islamic, Confucian, Japanese, Hindu, Buddhist, or Orthodox culture." Although Huntington conceded that a few civilizations might yet be won to the democratic cause, most, he implied, would not (Hefner, 2000).

In global Islamic populous perspectives, it's interesting to consider the pew Global Attitudes Project Survey in December 2002 and May 2003. The survey in December 2002 undertook $38 ; 000$ people in 44 nations covering attitudes on globalization, democratization, and the role of Islam in governance and society while the second survey of 16,000 people in 20 countries and the Palestinian Authority was undertaken after second Gulf/Iraq War.

The first survey showed that people in Muslim countries placed a high value on freedom of expression, freedom of the press, multi-party systems, and equal treatment under the law. This included people living in kingdoms such as Jordan and Kuwait, as well as those in authoritarian states like Uzbekistan and Pakistan. In fact, many of the Muslim publics polled expressed a stronger desire for democratic freedoms than the publics in some nations of eastern Europe, notably Russia and Bulgaria.

The second survey, postwar update found that in most Muslim populations, large majorities continue to believe that Westernstyle democracy could work in their countries. This was not only in the case of predominantly Muslim countries like Kuwait $(83 \%)$ and Bangladesh $(57 \%)$, but also in religiously diverse countries like Nigeria $(75 \%)$. There were no substantive differences between Muslims and non-Muslims in Nigeria on this point. Only in Indonesia $(53 \%)$ and Turkey $(37 \%)$ did substantial percentages say democracy was a Western way of doing things that would not work in their countries (Kohut, 2003).

Moreover, the surveys concluded that after Iraq war, the negative views of the United States among Muslims, which had been largely limited to countries in the middle East, had spread to Muslim populations in Indonesia and Nigeria. Since last summer, favorable ratings for the United States had fallen from $61(\%)$ to $15(\%)$ in Indonesia and from $71(\%)$ to $38(\%)$ among Muslims in Nigeria. In the wake of the war, a growing percentage of Muslims saw serious threats to Islam. Specifically, majorities in seven of eight Muslim populations surveyed expressed worries that the United States might become a military threat to their countries. Even in Kuwait, where people had a generally favorable view of the United States, 53 (\%) voice at least some concerned that the United States could someday pose a threat.

For the specific case to Indonesian Muslims, Center for the Study of Islam and society (PPIM), State Islamic University 
(SIU) Syarif Hidayatullah Jakarta had done a national wide survey to Understand the current religious phenomena in Indonesia. The survey was included 16 provinces was done in 2001. The survey confirmed the strengthening attachment of Indonesian Muslims to Islam. While the execution of santri (devout Muslim) religious rituals (such as fasting during Ramadhan, praying five times a day and pray before starting working) increased, the abangan (nominal Muslim) practices (such as giving ritual offering, burning incense and asking suggestion from a shaman) decreased. Among other things, the findings drew some light on the raise of Islamic political parties during the 1999 general election and the long debates, which followed the election, on the implementation of the shari'ah law in Indonesia and on whether or not to reinstate the Jakarta Charter in the UUD 45.

In year 2002, PPIM did another research with bigger sample, which all provinces were included. The survey showed that the strengthening of religious attachment coincides with the increasing tendency of fundamentalism. More people agreed with the application of Islamic government. While the majority of Indonesian Muslims were still moderate and tolerant, thanks to the important role played by mass Muslims organization especially Nahdatul Ulama (NU) and Muhammadiyah, the increasing tendency toward fundamentalism kegs an explanation. After the collapse of the New Order, Fundamentalism found its way gradually into the public sphere. It seemed that the suppression of any social and political, as well as ideological, movements detrimental to the New Order establishment had created a time bomb (Jumhari, 2003).

Comparing the findings of PPIM research in 2001 and 2002, one cannot underestimate the power of moderate groups in Indonesia. In 2001 about $45 \%$ of the respondent (or $42 \%$ in 2002) Indonesian Muslim feel that they are part of NU community. while $11 \%$ (or $12 \%$ in 2002 ) that of Muhammadiyah. The further interpretation of the relevant data from the questioner reveal that there is a close relationship between the attachment of the people to the Muslim mass organization and their agreement to civility and democracy. The more they attach to these organization the more they agree to civic democratic values. The acknowledging moderate Muslims in Indonesia is not only based on such as surveys, even Paul Wolvowitz, Deputy Secretary of Defense of United States of America admits and welcomes the prospect of moderate Muslim regime in Indonesia. The Interview was in Singapore with Stave Gugkin from Associate Press, and Richard Hubbard from Reuters, on June 1, 2002.

Moreover, considering the Bali blasting trial, the suspects claimed that they were only alien haters (particularly American, Israeli, Australian, and Englishman) rather than the Islamic strugglers. Their action was not based on the regional motives, but was based on hate for certain western policies in the world, particularly in Middle East and the civilians from that countries ware only the victims. According to the global survey that have presented above, it is not surprisingly. However, killing the civilians is strongly prohibited in every religion, particularly in Islam. For them who have killed uninnocent civilians, the equal punishments are reasonable.

\section{Conclusion}

In conclusion, it should be noted that problems of recovering foreign investment in Indonesia needed good cooperation and coordination among macroeconomic, monetary, and fiscal policies, supported by 
progress in the area of political and social restructuring. In the future, such coordination needs to be promoted, especially under the anticipated circumstances of greater challenges and uncertainties. However, the investment safety is the main key to recover the foreign investment in Indonesia. It was really realized that the worries of foreign investor to Indonesia seemed make sense. However, from the discussion above, investing in indonesia is relatively save. Lastly, it is not reasonable afraid of Indonesian Muslims.

\section{References}

Bank Indonesia, (2003), Annual Report 2002: The Evaluation of Monetary Policies in 2002 and Policy Directions for the year 2003, Jakarta.

Bank Indonesia, (2003), atwww.bi.go.id

Central Bureau of Statistics, (2002), Statistics of Indonesia, Jakarta.

Central Bureau of Statistics, BAPPENAS, and UNDP, (2001), Indonesia Human Development Report: Towards a New Consensus, Democracy, and Human Development in Indonesia, Jakarta.

Hefner, Robert W (2000), Civil Islam: Muslims and Democratization in Indonesia, Princeton University Press.

Indonesia Investment Board, (2003), at www.bkpm.go.id.

Indonesia Ministry of Finance, (2003), at unw.depkeu.go.id.

International Monetary Fund, (2003), International Financial Statistics.
Jamhari (2002), Indonesian Fundamentalism?, Volume 9, Number 3, 2002 at www.ppim.net.

Japan Bank for International Cooperation, (2002), JBIC FY 2001 Survey: The Outlook of Japanese Foreign Direct Investment, Journal of Research Institute for Development and Finance, No.9; January.

Kohut, Andrew, (2003), Anger at America Notwithstanding, Muslims Still Want Western System, Pew Research Center for The People and The Press (US) at www.worldpaper.com.

Tadjoeddin, M. Zulfan, (2002), Anatomy of Social Violence in the Context of Transition, The Case of indonesia 19902001, UNSFIR Working Paper, Jakarta

Urata, Sujiro (2002), Japanese Foreign Direct Investment in East Asia With Particular Focus on ASEAN4, Presented in the "Conference on Foreign Direct Investment: Opportunities and Challenges for Cambodia, Laos, and Vietnam". Hanoi, Vietnam, on August 1617, 2002.

US Embassy in Japan (2003), Transcript: Wolfowitz Welcomes Prospect of Moderate Muslim Regime in Indonesia, Interview in Singapore with Steve Gugkin, AP, and Richard Hubbard, Reuters. At http:/l usembassy.state.góv/tokyol www.2400f.html. 
Topik: Rekonstruksi Indonesia

Table 1. Indonesia's Macroeconomic Indicators

\begin{tabular}{|c|c|c|c|c|c|}
\hline Sector & 1998 & 1999 & 2000 & 2001 & 2002 \\
\hline Output and Growth (constant 1993 prices, \%) ${ }^{\prime \prime}$ & & & & & \\
\hline Gross Domestic Product (GDP) Growth & -13.1 & 0.9 & 4.8 & 3.3 & 3.7 \\
\hline Manufacturing industry & -11.4 & 3.8 & 6.2 & 4.1 & 4.0 \\
\hline Electricity, Gas, and Clean Water & 3.0 & 8.3 & 7.6 & 7.7 & 6.2 \\
\hline Transportation and Communication & -18.2 & -0.8 & 8.6 & 7.3 & 7.8 \\
\hline Financial, Ownership, and Business Services & -26.6 & -7.2 & 4.6! & 3.4 & 5.6 \\
\hline Growth by Expenditure (constant 1993 prices) ${ }^{2}$ & & . & & & \\
\hline Private Consumption & -6.2 & 4.6 & 1.6 & 4.4 & 4.7 \\
\hline Government Consumption & -15.4 & 0.7 & 6.5 & 9.0 & 12.8 \\
\hline Investment & -33.0 & -18.2 & 16.7 & 7.7 & .0 .2 \\
\hline Saving & -28.1 & -10.3 & 15.7 & -1.1 & -2.8 \\
\hline Export & 11.2 & -31.8 & 26.5 & 1.9 & -1.2 \\
\hline Imports & -5.3 & -40.7 & 25.9 & 8.1 & .8 .3 \\
\hline Govemment Finance (end of period) ${ }^{d}$ & & & & & \\
\hline Revenue and Grants (Rp trillion) & 120.0 & 152.4 & 204.9 & 299.7 & 300.2 \\
\hline Expenditure & 129.1 & 185.9 & 220.9 & 334.0 & 327.9 \\
\hline Overall Fiscal Surplus/Deficit & -9.0 & -33.5 & -16.0 & -34.3 & -27.7 \\
\hline Overall Fiscal SurplusDeficit (\% of GDP) & -0.9 & -3.0 & -1.3 & -2.4 & -1.7 \\
\hline Balance of Payments ${ }^{b}$ & & & & & \\
\hline Current Account Balance (\% of GDP) & 4.2 & 4.1 & 3.4 & 4.7 & 3.9 \\
\hline . Capital Account Balance (\% of GDP) & -4.0 & -3.2 & -2.9 & -6.1 & -1.9 \\
\hline Money, inflation, and Interest Rates $b, c$ & & & & & \\
\hline Money Supply (M2, annual \% change) & 62.3 & 11.9 & 15.6 & 13.0 & 4.7 \\
\hline Consumer Price Index (end of period, annual \% change) & 77.6 & 1.9 & 9.3 & 12.5 & 10.0 \\
\hline Money Market Rate $(\%)$ & 62.8 & 23.6 & 10.3 & 15.0 & 13.5 \\
\hline Deposit Rate: 6 months (end of period, \%) & 39.1 & 25.7 & 12.5 & 15.5 & 15.5 \\
\hline Population and Labor Force" & & & & & \\
\hline Population (million) & 199 & 200 & 206 & 209 & 212 \\
\hline Annual Population Growth (\%) & 1.80 & 0.92 & 2.75 & 1.49 & 1.48 \\
\hline Labor Force (million) & 92.7 & 94.8 & 95.7 & 98.8 & 100.5 \\
\hline Open Unemployment Rate (\%) & 5.5 & 6.4 & 6.1 & 8.11 & 9.1 \\
\hline Labor Force Participation Rate (\%) & 66.9 & 67.2 & 67.8 & 68.6 & 67.8 \\
\hline Extemal Debt Outstanding (end of period) & & & & & \\
\hline Total (US\$ million) & 150,886 & 148,098 & 141,693 & 133,074 & 131,343 \\
\hline Public & 67,329 & 75,862 & 74,916 & 71,378 & 71,378 \\
\hline Private & 83,557 & 72,236 & 66,777 & 61,696 & 59,965 \\
\hline External Payments Indicators b & & & & & \\
\hline Gross Oficiat Reserves (US\$ billion) & 23.8 & 27.1 & 29.4 & 29.0 & 31.6 \\
\hline Average Exchange Rate (Rp/USS) & 7,590 & 9,595 & 9,350 & 10,288 & 9,316 \\
\hline GOP (current prices, Rp trilion) & 955.8 & $1,099.7$ & $1,264.9$ & $1,449.4$ & $1,610.0$ \\
\hline Per capita GOP (current prices, USS) & 491.1 & 696.5 & 732.1 & 677.7 & 810.8 \\
\hline
\end{tabular}

\section{Source:}

a. Center Bureau of Statisties;

b. Bank of Indonesia;

c. Intemational Financial Statistics;

d. Ministry of Finance. 
The Way of Indonesia to Attract and...; Hasjim Muzadi; Mas'ud Machfudz .

Table 2. Trend of Investment Approvals 1967-2003

\begin{tabular}{|c|c|c|c|c|}
\hline \multirow{2}{*}{ Year } & \multicolumn{2}{|c|}{ Domestic Investment } & \multicolumn{2}{c|}{ Foreign Investment } \\
\cline { 2 - 5 } & Number of & Value & Number of & Value \\
\cline { 2 - 5 } & Projects (P) & (Rp. Billion) (l) & Projects (P) & (US\$. Million) (l) \\
\hline $1967-1990$ & 7,067 & $133,656.0$ & 1,824 & 34,723 \\
\hline 1991 & 808 & $41,210.8$ & 390 & $9,030.2$ \\
\hline 1992 & 422 & $29,395.9$ & 304 & $10,466.1$ \\
\hline 1993 & 547 & $39,715.9$ & 330 & $8,153.8$ \\
\hline 1994 & 825 & $53,598.3$ & 444 & $27,046.4$ \\
\hline 1995 & 793 & $69,844.7$ & 782 & $39,891.6$ \\
\hline 1996 & 807 & $97,401.1$ & 947 & $29,941.0$ \\
\hline 1997 & 723 & $119,877.2$ & 781 & $33,788.8$ \\
\hline 1998 & 327 & $57,973.6$ & 1,034 & $13,649.8$ \\
\hline 1999 & 237 & $53,540.7$ & 1,177 & $10,884.5$ \\
\hline 2000 & 392 & $93,897.1$ & 1,541 & $16,075.9$ \\
\hline 2001 & 264 & $58,816.0$ & 1,333 & $15,055.9$ \\
\hline 2002 & 185 & $25,172.3$ & 1,150 & $9,795.3$ \\
\hline 2003 & 95 & $8,171.2$ & 497 & $4,373.1$ \\
\hline Total & 13,492 & 882,271 & 12,534 & 262,875 \\
\hline
\end{tabular}

Source: Indonesia Investment Board (2003).

Note:

1. Excluding of Oil \& Gas, Banking, Non Bank Financial Institution, Insurance and Leasing;

2. $P=$ Number of Projects $=$ New Project + Change of Status:

3. I = Investment Value $=$ New Project + Expansion + Change of Status;

4. Tentative data, including approvals issted by regions received by BKPM until June 30, 2003.

Table 3. Trend of Foreign Investment Approvals by Sector, $1998-2002$

\begin{tabular}{|c|c|c|c|c|c|c|c|c|c|c|c|}
\hline \multirow{2}{*}{ NO } & \multirow{2}{*}{ Sector } & \multicolumn{2}{|c|}{1998} & \multicolumn{2}{|c|}{1999} & \multicolumn{2}{|c|}{2000} & \multicolumn{2}{|c|}{2001} & \multicolumn{2}{|c|}{2002} \\
\hline & & $\mathbf{P}$ & 1 & $P$ & 1 & P & 1 & $\underline{p}$ & J & $P$ & 1 \\
\hline 1 & Primary Sector & 150 & $1,013.7$ & 55 & 654.0 & 74 & $594 . \dot{8}$ & 55 & 511.7 & 41 & 508.2 \\
\hline$\|$ & Secondary Sector & 407 & $8,529.4$ & 441 & $6,907.6$ & 499 & $10,760.1$ & 425 & $5,148.3$ & 335 & $3,258.2$ \\
\hline Iil & Tertiary Sector & 477 & $4,106.7$ & 681 & $3,322.9$ & 968 & $4,721.0$ & 853 & 9.395 .9 & 774 & 6.028 .9 \\
\hline IV & Total & 1,034 & $13,648,8$ & 1,177 & $10,884.5$ & 1,541 & $16,075.9$ & 1,333 & $15,055.9$ & 1,150 & $9,795.3$ \\
\hline
\end{tabular}

Source and Note: see Table 2. 
Topik: Rekonstruksi Indonesia

Table 4. Trend of Foreign Investment New Approvals, Expansion \& Change of Status by Sector, 2003

\begin{tabular}{|c|c|c|c|c|c|c|c|}
\hline \multirow{3}{*}{ NO } & \multirow{3}{*}{ Sector } & \multicolumn{6}{|c|}{2003} \\
\hline & & \multicolumn{2}{|c|}{ New } & \multicolumn{2}{|c|}{ Expansion } & \multicolumn{2}{|c|}{ Change of Status } \\
\hline & & $P$ & 1 & $\mathbf{P}$ & 1 & $\underline{P}$ & 1 \\
\hline I & Primary Sector & 15 & 74.2 & 4 & 6.1 & 3 & 17.5 \\
\hline 1 & Food Crors \& Plantation & 2 & 1.7 & -1 & -1 & 1 & 14.0 \\
\hline 2 & Livestock & 2 & 4.5 & 3 & 5.8 & - & - \\
\hline 3 & Forestry & 1 & 31.4 & $\therefore$ & -1 & - & - \\
\hline 4 & Fishing & 5 & $25: 2$ & 11 & 0.3 & 1 & 0.4 \\
\hline 5 & Mining & 5 & 11.4 & .1 & -1 & 1 & 3.1 \\
\hline 11 & Secondary Sector & 125 & 712.6 & 84 & 325.3 & 16 & 216.6 \\
\hline 6 & Food Industry & 9 & 51.4 & 7 & 23.3 & 1 & 13.6 \\
\hline 7 & Textile industy & 11 & 9.8 & 9 & 36.2 & .5 & 57.9 \\
\hline 8 & Leather Goods \& Footwear Industy & 3 & 2.7 & 1 & 2.6 & 2 & 21.5 \\
\hline 9 & Wood Industry & 3 & 22.5 & 5 & $13: 1$ & 1 & 16.1 \\
\hline 10 & Paper and Printing Industry & 5 & 3.6 & 3 & 4.8 & -1 & \\
\hline 11 & Chemical and Pharmaceutical Industy. & 12 & 34.6 & 13 & 80.1 & 3 & 81.7 \\
\hline 12 & Rubber and Plastic Industry & 13 & 30.3 & 5. & 30.2 & $=1$ & $\therefore$ \\
\hline 13 & Non Metallic Mineral Industry & 2 & 480.2 & 1 & 2.0 & 3 & 24.6 \\
\hline 14 & Metal, Machinery \& Electronic Industry & 49 & 63.5 & 28 & 70.6 & 1 & 1.2 \\
\hline 15 & Medical Preci. \& Optical Instru, Watches \& Clock & 3 & 2.4 & -1 &. & -1 & - \\
\hline 16. & Motor Vehicles \& Other Transport Equip ind. & 7 & 9.6 & 9 & 61.0 & -1 & - \\
\hline 17 & Other Industry & 8. & 20 & 3 & 1.4 & -1 & 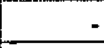 \\
\hline III & Tertiany Sector & 300 & 597.9 & 51 & 253.4 & 38 & $2,169.5$ \\
\hline 18 & Electricity, Gas \& Water Supply & 1 & 226.1 & 1 & 76.6 & $\therefore$ & 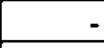 \\
\hline 19 & Construction & 9. & 28.6 & 6 & 18.5 & 4. & 109.2 \\
\hline 20 & Trade \& Repair & 178 & 63.9 & 23 & 89.3 & 14 & 33.9 \\
\hline 21 & Hotel \& Restaurant & 23 & 37.1 & 2 & 28.9 & 8 & 226.1 \\
\hline 22 & Transport, Storage \& Communication & 20 & 185.5 & 7 & 31.4 & 7 & $1,745.4$ \\
\hline 23 & Real Estate, Ind. Estate \& Business Activities & 1 & 0.2 & 2 & 2.5 & -1 & \\
\hline 24 & Other Services & 68 & 56.5 & 10 & 6.2 & 5 & 54.9 \\
\hline IV & Total & 440 & $1,384,7$ & 139 & 584.8 & 57 & $2,403.6$ \\
\hline
\end{tabular}

Source and Note: see Table 2. 
The Way of Indonesia to Attract and...; Hasjim. Muzadi; Mas'ud Machfudz

Table 5. Trend of Foreign Investment Approvals by Location, 1998 - 2002

\begin{tabular}{|c|c|c|c|c|c|c|c|c|c|c|c|}
\hline \multirow{2}{*}{ No. } & \multirow{2}{*}{ Location } & \multicolumn{2}{|c|}{1998} & \multicolumn{2}{|c|}{1999} & \multicolumn{2}{|c|}{$2000^{\circ}$} & \multicolumn{2}{|c|}{2001} & \multicolumn{2}{|c|}{2002} \\
\hline & & $P$ & 1 & $p$ & 1 & $\mathbf{P}$ & 1 & $p$ & i & $p$ & 1 \\
\hline 1. & Sumatra & 150 & $1,400.6$ & 134 & $7,640.4$ & 164 & $3,072.1$ & 143 & $2,356.7$ & 106 & $2,070.3$ \\
\hline 1 & N. Aceh Danussalam & 8 & 6.2 & $4^{:}$ & 51.8 & 3 & $1,811.1$ & 2 & 6.0 & 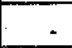 & . \\
\hline 2 & North'Sumatera & 21 & 209.5 & 27 & 102.7 & 25 & 160.2 & 28 & .106 .5 & 4 & 44.4 \\
\hline 3 & West Sumatera & 8 & 175.8 & 7 & 342.8 & 4 & 19.0 & 6 & 38.2 & . & 10.0 \\
\hline 4 & Riau & 85 & 548.2 & 80 & $6,946.5$ & 98 & 374.5 & 87 & 2.095 .5 & 83 & $1,153.0$ \\
\hline 5 & Jambi. & 5 & 201.9 & 4. & 41.9 & 11 & 360.9 & 6 & $10: 2$ & 6 & 21.6 \\
\hline 6 & South Sumatesa & 8 & $123.0^{3}$ & 3 & 35.6 & 5 & 96.0 & $\theta$ & 42.3 & 3 & 724.4 \\
\hline 7 & Bengkulu & 5 & 37.7 & 2 & 18.4 & 1 & 0.6 & 1 & 1.9 & - & 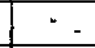 \\
\hline 8 & Làmpung & 8 & 98.1 & 6 & 96.2 & 10 & 97.4 & 5 & 53.8 & 4 & 85.7 \\
\hline 9 & Bangka Belitung & 2 & $\delta .2$ & 1 & 4.5 & 4 & 152.4 & 2 & 2.3 & 6 & 31.2 \\
\hline 11 & Java: & 684 & $10,881.4$ & 855 & $2,651.4$ & 1,195 & $11,053.6$ & 995 & $5,741.8$ & 896 & $4,799.4$ \\
\hline 10 & Jakarta C.T & 330 & $1,724.9$ & 435. & 786.2 & 737 & $3,257.1$ & 605 & $1,154.5$ & 588 & $3,378.6$ \\
\hline 11 & West Java & 159 & $1,568,8$ & 174 & $1,244.0$ & 210 & 1.770 .4 & 201 & $1,190.9$ & 164 & 897.6 \\
\hline 12 & Central Java & 39 & $3,074.3$ & 58 & 68.1 & 38 & $3,085.4$ & 43 & 117.1 & $\therefore 1$ & 71.6 \\
\hline 13 & S. R. of Yogyakana & 10 & 5.9 & 11 & 10.8 & 20 & 504.3 & 10 & 10.2 & 9 & 19.9 \\
\hline 14 & East Java & 67. & $580: 7$ & 67 & 283.5 & 61 & 1,135.3. & 23 & $1,680.6$ & 22 & 271.1 \\
\hline 15 & Banten & 79 & $3,926.8$ & 110 & 258.8 & 129 & $1,301.1$ & 113 & 1.588 .5 & 82 & 160.6 \\
\hline III & Bali \& Nuss Tenggarm & 82 & 364.9 & 147 & 199.1 & 136. & $1,614.4$ & 129 & 524.9 & 97 & 208.7 \\
\hline 16 & Bali. & 73 & 307.7 & 127 & 183.9 & 126 & 201.5 & 116 & 518.9 & 82 & $86 . \bar{v}$ \\
\hline 17 & West Nusa Tenggara & 14. & 19.3 & 19 & 13.8 & 8 & $1,407.9$ & 12. & 4.8 & 13 & 197 \\
\hline 18 & East Nusa Tenggara & 5 & 37.9 & 1 & 1.4 & 2 & 5.0 & 1 & 1.2 & 2 & 2,5 \\
\hline$N$ & Kalimantan & 62 & 722.7 & 11 & 226.8 & 22 & 208.8 & 43 & 246.6 & 29 & $2,237.0$ \\
\hline 19 & West Kalimantan & 17 & 251.2 & 6 & 102.0 & 2 & 2.9 & $\varepsilon$ & 21.8 & 1 & 1.4 \\
\hline 20 & Central Kalimantan & 17 & 0.4 & 2 & 50,3 & 5 & 74.7 & 3 & 11,9 & 2 & 8.9 \\
\hline 21 & South Kalimantan & 8 & 73.4 & 1 & 30.3 & 2 & .3 .1 & 6 & 9.7 & 1 & 34.0 \\
\hline 22 & East Kalimantan & 20 & 397.7 & 2 & 44.2 & 13 & 128.1 & 28 & 203.2 & 25 & $2,192.7$ \\
\hline$v$ & Sulawesl & 28 & 257.8 & 25 & 141.8 & 23 & 74.4 & 16 & 81.1 & 16 & 4202 \\
\hline 23 & North Sulawasi & 10 & 158.1 & 14 & 25.1 & 10 & 25.5 & 2 & 1,2 & 4 & 41.2 \\
\hline 24 & Central Sulawesj & 5 & 71.2 & 2 & 1.7 & 1 & 1.5 & 4 & 0.5 & 2 & 0.3 \\
\hline 25 & South Sulamosi & 10 & $27.8^{\circ}$ & 3 & 12.5 & 8 & 39.2 & 9 & 78.9 & 9 & 373.7 \\
\hline 26 & South East Sulawesi & 1 & 0.6 & 6 & 102.5 & 3 & 8.0 & 1 & 0.5 & 1 & $5.0^{\circ}$ \\
\hline 27 & Gorontalo & 2 & 0.1 & - & - & 1 & 0.2 & - & $=$ & . & . \\
\hline n & Maluku & 8 & 5.2 & 3 & 1.8 &. & 0.1 & 3 & 9.3 & $\therefore$ & . \\
\hline 28 & Maluku & 5 & 5.2 & 1 & 0.9 & $\therefore$ & 0.1 & 1 & 0.6 & - & $\therefore$ \\
\hline 29 & North Maluku & 3 & - & 2 & 0.9 & $\therefore$ & - & 2 & 8.7 & $\therefore$ & - \\
\hline VII & Papua & 10 & 11.2 & 2 & 23.2 & 4 & 52.5 & 4 & $6,095.5$ & 6 & 59.7 \\
\hline 30 & Papua & 10 & 11.2 & 2 & 23.2 & 4 & 52.5 & 4 & $6,095,5$ & 6 & 59.7 \\
\hline $\mathrm{VIH}$ & Total & 1,034 & $13,849.8$ & 1,177 & $10,884.5$ & 1,541 & $16,075.9$ & 1,333 & $15,055.9$ & 1,150 & $9,795.3$ \\
\hline
\end{tabular}

Soujce and Note: see Table 2. 


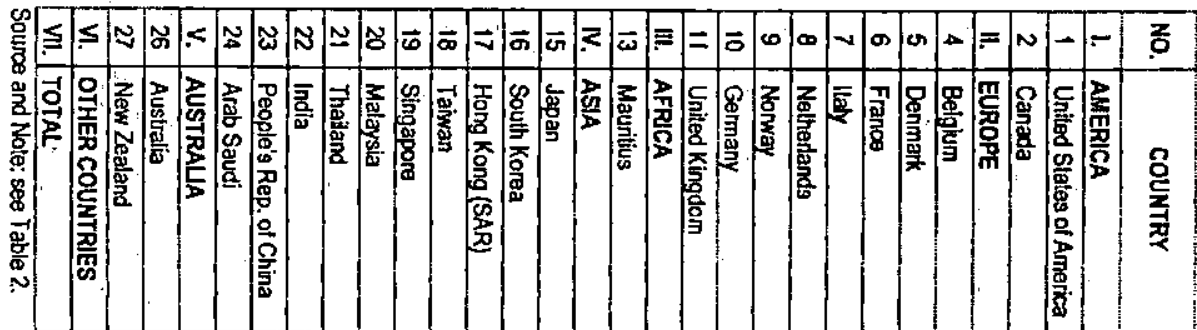

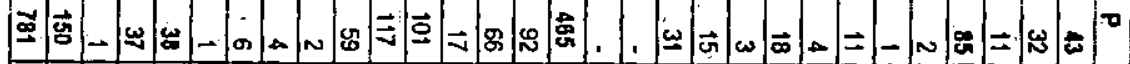

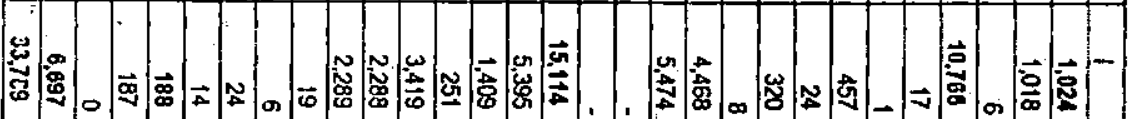

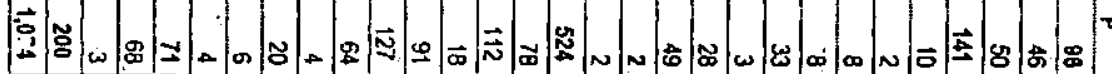

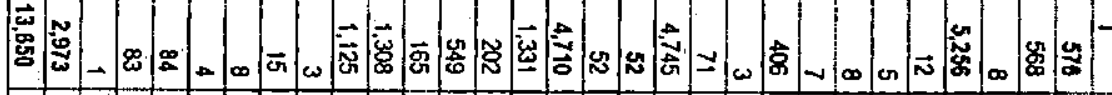

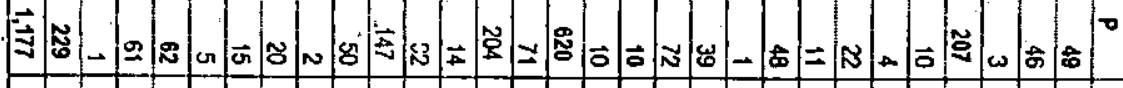

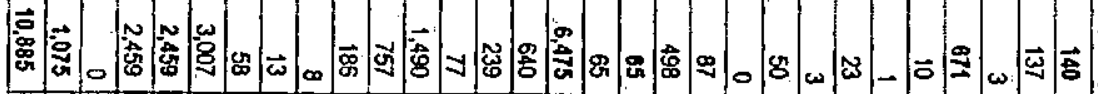

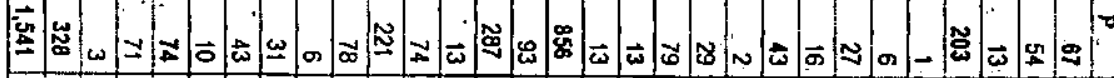

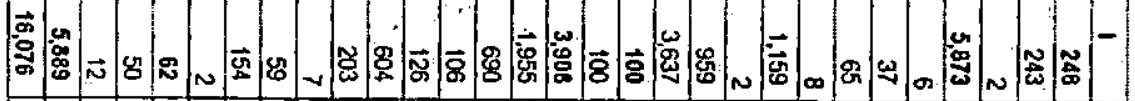

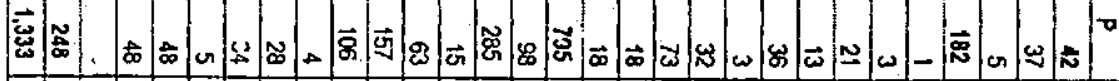

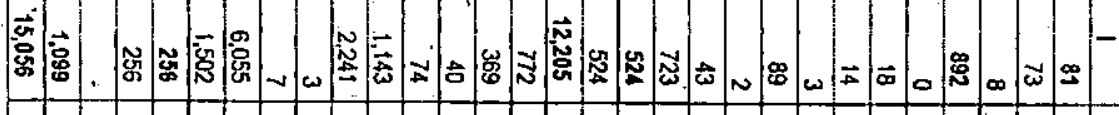

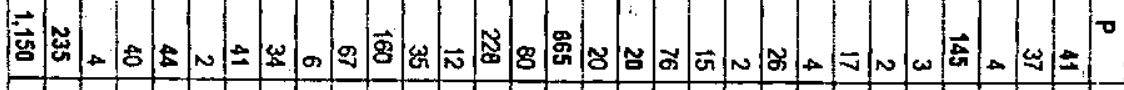

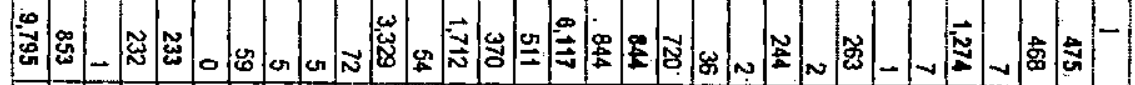

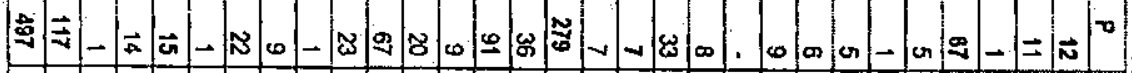

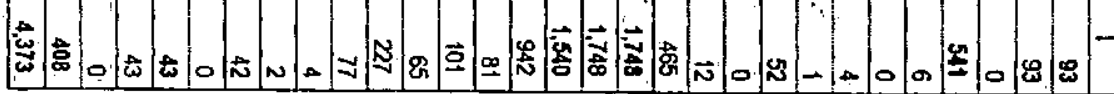


The Way of Indonesia to Attract and...; Hasjim Muzadi; Mas'ud Machfudz

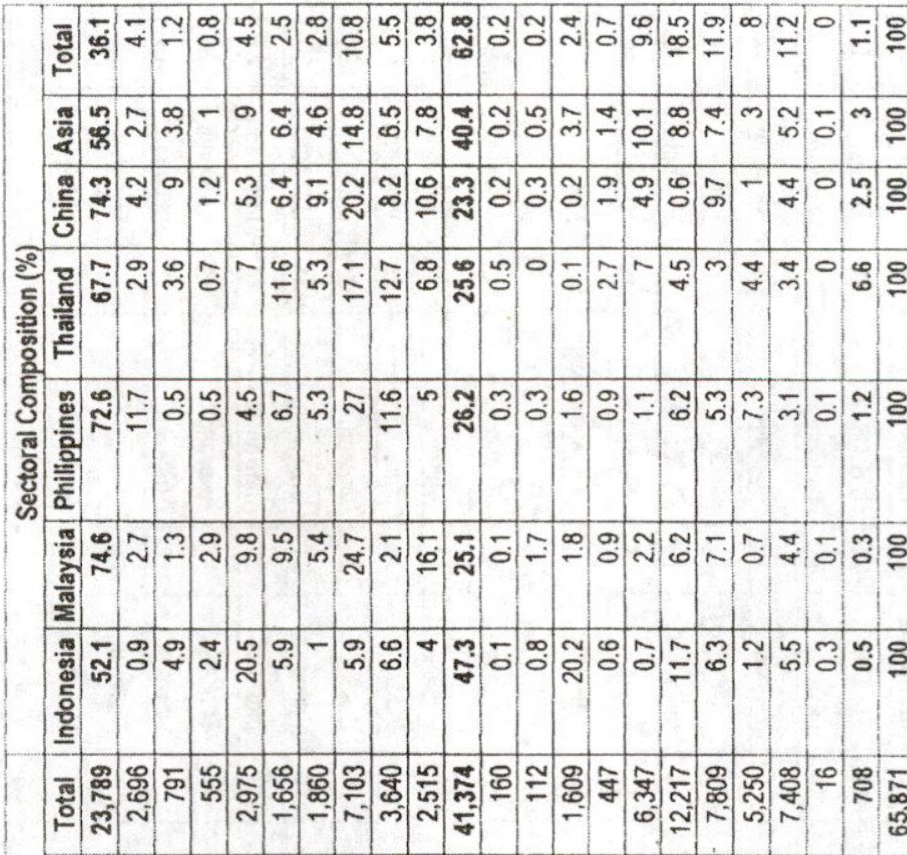

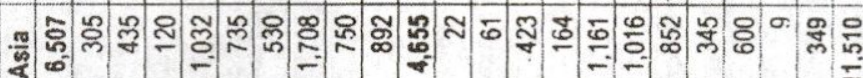
๕

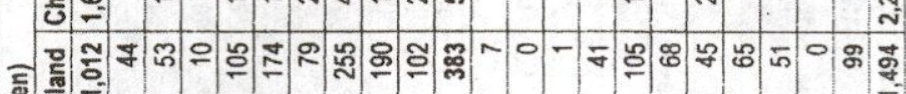
해

ஜ 그

突 흘 ๘ 高 产 요드.

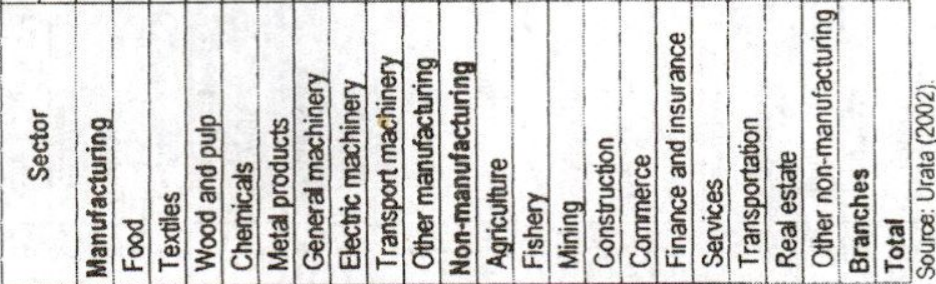


Modlum-term (next 3 years)

\begin{tabular}{|c|c|c|c|c|c|c|c|c|c|c|c|c|c|c|}
\hline No & 2001 & $\%$ & 2000 & $\%$ & 1999 & $\%$ & 1998 & $\%$ & 1997 & $\%$ & 1996 & $\%$ & 1995 & $\%$ \\
\hline 1 & China & 82 & China & 65 & China & 55 & China & 55 & China & 64 & China & 68 & China & 74 \\
\hline 2 & U.S.A. & 32 & U.S.A. & 41 & U.S.A. & 39 & U.S.A. & 41 & U.S.A. & 36 & Thatand & 36 & Thailand & 36 \\
\hline 3 & Thailland & 25 & Thalland & 24 & Thailand & 27 & Thaland & 23 & Indonesia & 28 & Indonesia & 34 & Indonesia & 33 \\
\hline 4 & Indonesia & 14 & Indonesia & 15 & India & 15 & Indonesia & 16 & Thatland & 25 & U.S.A. & 32 & U.S.A. & 32 \\
\hline 5 & India & 13 & Malaysia & 12 & Indonesia & 15 & India & 15 & India & 23 & Vielnam & 27 & Vielnam & 28 \\
\hline 6 & Vietnam & 12 & Taiwan & 11 & Vietnam & 11 & Philippines & 14 & Vietnam & 19 & Malaysia & 20 & Malaysia & 22 \\
\hline 7 & Taiwan & 11 & India & 10 & Malaysia & 9 & Malaysia & 14. & Philippines & 14 & India & 18 & India & 17 \\
\hline 8 & Korea & 8 & Vietnam & $9:$ & Philppines & 9 & Vielnam & 14 & Malaysia & 13 & Philippines & 13 & Philippines & 15. \\
\hline 9 & Malaysia & 8 & Korea & 9 & U.K. & 9 & Brazi & 11 & Brazi & 8 & Singapore & 10 & Singapore & 10 \\
\hline 10 & Singapore & 6 & Philppines & 8 & Brazi & 8. & U.K. & 10 & Taiwan & 8 & U.K. and Taiwan & 73 & U.K. & 7 \\
\hline \multicolumn{15}{|c|}{ Long-term (next 10 years) } \\
\hline No & 2001 & $\%$ & 2000 & $\%$ & 1999 & $\%$ & 1998 & $\%$ & 1997 & $\%$ & 1996 & $\%$ & 1995 & $\%$ \\
\hline 1 & China & 86 & China & 70 & China & 66 & China & $6 \dot{4}$ & China & 73 & China & 74 & China & 78 \\
\hline 2 & India: & 28 & U.S.A. & 38 & U.S.A. & 30 & U.S. & 34 & India & 36 & India & 39 & Vielnam & 41 \\
\hline 3. & U.S.A. & 25 & India & 22 & India & 27 & India & 25 & U.S. & 31 & Vietnam- & 33. & India & 36 \\
\hline 4 & Thailand & 19 & Thailand & 21 & Thalland & 24. & Indonesla & 20 & Vielnam & 24 & U.S.A. & $31^{\circ}$ & U.S.A. & 30 \\
\hline 5 & Vietnam & 14 & Indonesla & 14 & Vietnam & 18 & Thadand & 19 & Indonesia & 21 & Indonesia & 24 & Indonesia & 24 \\
\hline 6 & Indonesia & 14 & Vietnam & 14 & Indonesia & 18 & Vielnam & 18 & Thailand & 16. & Thailand & 24 & Thailand & 24 \\
\hline 7 & Brazil & 8 & Malaysia & 10 & Brazil & 14 & Brazi & 14 & Erazi & 11 & Malaysia & 12 & Myanmar & 15 \\
\hline 8 & Taiwan & 7 & Brazil & 9 & Malaysia & 8 & Philippines & 13 & Philippines & 11 & Myanmar & 11. & Malaysia & 13 \\
\hline 9 & Malaysia & 6 & U.K. & 9 & Phalippines & 8 & Malaysia & 7 & Malaysia & 9 & Philippines & $\therefore$ & Fhilippines & 1.1 \\
\hline 10 & Korea and Philippines & $5 \mathrm{a}$ & Taiwan & 8 & Mexico & 7 & U.K. & 6 & Myanmar & 5 & Mexico & 6 & U.K. & 6 \\
\hline
\end{tabular}

Source; Japan Bank for International Cooperation (2002) and Urata (2002).

Note: a. \% for each county. 
The Way of Indonesia to Attract and...; Hasjim Muzadi; Mas'ud Machfudz

Table 9. The Problems Faced by Japanese Firms (\%)

\begin{tabular}{|c|c|c|c|c|c|}
\hline Problems & Thailand & Indonesla & Malaysia & Vielnam & China \\
\hline Under developed infrastructure & 14.9 & 24.1 & 14.3 & 38.6 & 27.3 \\
\hline Legal system (underdevelopment) & 17.2 & 25.9 & 7.1 & 36.4 & 43.8 \\
\hline Legal system (lack of transparency) & 14.9 & 16.7 & 7.1 & 20.5 & 53.3 \\
\hline Legal system (instability) & 5.7 & 16.7 & 3.6 & 15.9 & 52.1 \\
\hline Tax system (complicated system) & 4.6 & 7.4 & 3.6 & 2.3 & $\$ 6.8$ \\
\hline Tax system (lack of transparency) & 13.8 & 7.4 & 7.1 & 11.4 & $? 6.5$ \\
\hline Tax syslem (instability) & 2.3 & 7.4 & 3.6 & 11.4 & 42.2 \\
\hline Tax system (high tarif rates) & 10.3 & 5.6 & 0 & 9.1 & 17.5 \\
\hline Restriction on equity participation & 10.3 & 7.4 & 32.1 & $\uparrow 1.4$ & 20.3 \\
\hline Complicated administralive procedure & 5.7 & 3.7 & 17.9 & 15.9 & 34.9 \\
\hline Political and social instability & 11.5 & 94.4 & 32.1 & 25 & 34 \\
\hline Unstable exchange rates & 48.3 & 57.4 & 32.1 & 22.7 & 15.2 \\
\hline Difficulty in procuring local parts & 19.5 & 11.1 & 17.9 & 34.1 & 20.6 \\
\hline Underdevolopment of supporting industry & 10.3 & 13 & 0 & 22.7 & 10.2 \\
\hline Difficulty in obtaining finance & 11.5 & 11.1 & 17.8 & 9.1 & 16.2 \\
\hline Tough competition & 29.9 & 20.4 & 21.4 & 13.6 & 23.8 \\
\hline Difficulty in recruiting managers & 23 & 11.1 & 28.6 & 20.5 & 19.7 \\
\hline Difficulty in recruiting workers & 13.8 & 11.1 & 14.3 & 9.1 & 10.5 \\
\hline Increase in wages & 20.7 & 11.1 & 21.4 & 6.8 & 14 \\
\hline Labor disputes & 9.2 & 11.1 & 3.6 & 2.3 & 12.7 \\
\hline Short age of information on the host country & 4.6 & 5.6 & 0 & 18.2 & 9.5 \\
\hline Others & 0 & $\underline{0}$ & 3.6 & 0 & 0.3 \\
\hline The number of respondents & 87 & 54 & 28 & 44 & 315 \\
\hline
\end{tabular}

Source: Japan Bank for International Cooperation (2002) and Urata (2002). 
Topik: Rekonstruksi Indonesia

Table 10. Classification of Conflict Area in Indonesia, 1990-2001

\begin{tabular}{|c|c|c|c|c|c|}
\hline \multirow[b]{2}{*}{ Provinces } & \multicolumn{2}{|c|}{ Number of Incidents } & \multicolumn{2}{|c|}{ Number of Deaths } & \multirow{2}{*}{$\begin{array}{l}\text { The Most dominant } \\
\text { category of social violence } \\
\text { (based on the biggest } \\
\text { number of deaths) }\end{array}$} \\
\hline & Total & $\begin{array}{c}\text { With } \\
\text { minimum } \\
\text { one death }\end{array}$ & Total & $\begin{array}{c}\text { Per } 100 \text { thousand } \\
\text { population }\end{array}$ & \\
\hline (1) & (2) & (3) & (4) & (5) & (6) \\
\hline High Conflict Area b & & & & & \\
\hline Maluku & 165 & 138 & 1,949 & 93.4 & Communal $(100 \%)$ \\
\hline N. Aceh Darussalam & 464 & 341 & 1,238 & 32.2 & Separatism $(100 \%)$ \\
\hline Central Kalimantan & 16 & 13 & 440 & 27.0 & Communal $(100 \%)$ \\
\hline Medium Conflict Area b & & & & & \\
\hline Central Sulawesi & 15 & 10 & 334 & 17.2 & Communal $(100 \%)$ \\
\hline Jakarta C. T & 55 & 16 & 1,230 & 13.5 & Communal $(98 \%)$ \\
\hline West Kalimantan & 17 & 9 & 442 & 12.2 & Communal $(100 \%)$ \\
\hline Papua & 41 & 29 & 136 & 7.0 & Separatism $(97 \%)$ \\
\hline South Kalimantan & 1 & 1 & 124 & 4.3 & Communal $(100 \%)$ \\
\hline East Nusatenggara & 14 & 8 & 55 & 1.5 & Communal $(96 \%)$ \\
\hline Riau & 17 & 4 & 26 & 0.7 & Communal $(96 \%)$ \\
\hline West Nusatenggara & 12 & 6 & 24 & 0.7 & Communal $(88 \%)$ \\
\hline Low Conflict Area ${ }^{b}$ & & & & & \\
\hline Bali & 9 & 5 & 14 & 0.5 & Communal $(100 \%)$ \\
\hline North Sulawesi & 3 & 1 & 9 & 0.3 & Communal $(100 \%)$ \\
\hline South Sulawesi & 14 & 3 & 20 & 0.3 & Communal (100\%) \\
\hline West Java & 88 & 28 & 71 & 0.2 & Communal $(87 \%)$ \\
\hline Lampung & 20 & 5 & 11 & 0.2 & - \\
\hline Central Java & 52 & 17 & 42 & 0.1 & Communal $(90 \%)$ \\
\hline North Sumatra & 24 & 7 & 11 & 0.1 & Communal $(45 \%)$ \\
\hline East Java & 32 & 10 & 29 & 0.1 & Communal $(78 \%)$ \\
\hline S. R. Yogyakarta & 9 & 2 & 2 & 0.1 & - \\
\hline West Sumatra & 6 & 1 & 1 & 0.0 & - \\
\hline Jambi & 7 & - & . & . & - \\
\hline South Sumatra & 7 & - & - & - & - \\
\hline East Kalimantan & 4 & - & $\cdot$ & - & . \\
\hline Southeast Sulawesi & 1 & - & - & - & - \\
\hline Bengkulu & & - & - & - & - \\
\hline Total & 1,093 & 654 & 6,208 & 3.2 & . \\
\hline
\end{tabular}

Source: Tadjoeddin (2002)

Notes: a) Weighted by the number of population based on SUPAS 1995

b) Classifying provinces into high, medium, and low conflict areas based on the data range of conflict severity, i.e. death intensity (column 5). Statistically the data do not spread normally, so the average is not good indicator used as the measure of data concentration. Therefore, to classify the provinces according to the severity of violence, the median (the value is 0.7 ) and standard deviation (the value is 21.3 ) approach is used (see footnote 47 for the explanation of this approach). The classification is as follows: - High conflict area: Death per 100 thousand population ' 22 - Medium conflict area: 0.7 _ death per 100 thousand population < 22 - Low conflict area: Death per 100 thousand population < 0.7 
The Way of Indonesia to Attract and...; Hasjim Muzadi; Mas'ud Machfudz

Table 11. Area Classification of Communal Violence, 1990-2001

\begin{tabular}{|c|c|c|c|c|c|c|}
\hline Ares Classlfication & $\begin{array}{c}\text { Number of } \\
\text { deaths }\end{array}$ & $\begin{array}{l}\% \text { to lotal } \\
\text { death }\end{array}$ & $\begin{array}{l}\% \text { pop (to total } \\
\text { Indonesia) }\end{array}$ & $\begin{array}{l}\text { Number of } \\
\text { cityldistric! }\end{array}$ & $\begin{array}{l}\text { \% to tolal } \\
\text { cl.yidistricl }\end{array}$ & $\begin{array}{l}\text { \% ! : all } \\
\text { cityidistrica }\end{array}$ \\
\hline $\begin{array}{l}\text { Exireme Vicience (death per } 100 \text { thousand } \\
\text { pop. }=39.7 \text { ) }\end{array}$ & 3,088 & 64.72 & \& 1.94 & $8^{\circ}$ & 12 & 4.12 \\
\hline $\begin{array}{l}\text { Medium Violence }(0.54=\text { death per } 100 \\
\text { thousand pop. }<39.7\end{array}$ & 1,594 & 33.41 & 1.00 & 27 & 41 & 13.91 \\
\hline $\begin{array}{l}\text { Low Violence (death per } 100 \text { thousand } \\
\text { pop. }<0.54 \text { ) }\end{array}$ & 89 & 1.87 & 0.06 & 今1 & 47 & 15.99 \\
\hline Total & 4,771 & 100.00 & 3.00 & 66 & $100^{c}$ & 34.01 \\
\hline
\end{tabular}

Source: Tadjoeddin (2002).

Nole:

a. Based on Inter Census Population Survey (SUPAS) 1995.

b. Extreme violence areas consist of 8 districts/cities, i,e. all (5) districts in Maluku, pl's Poso, Sambas and Kotawaringin

Timur (Sampit).

c. Total citiesidistricts based in $1999=294$. In 2003 had expanded to be 496 (Central Bureau of Stalistics).

Table 12. Bilateral Relevance Agreements to Investment

\begin{tabular}{|c|c|c|c|}
\hline \multicolumn{2}{|c|}{$\begin{array}{l}\text { Avoidance of Double } \\
\text { Taxation Agreements }\end{array}$} & \multicolumn{2}{|c|}{$\begin{array}{l}\text { Bilaterally the Investment } \\
\text { Promotion and Protection Agreements }\end{array}$} \\
\hline Australia & Seychelles & Argentina & Mozambique \\
\hline Austria & Singapore & Alger & The Netherlands \\
\hline Beigium & Slovak & Australia & Nonway \\
\hline Bulgaria & South Africa & Bangladesh & Pakistan \\
\hline Canada & South Korea & BelgiumLuxembourg & The Philippines \\
\hline Czech & Spain & Cambodia & Polant \\
\hline Denmark & Sri Lanka & Chile & Qatar \\
\hline Finiand & Sudan & People Rep. of China & Romania \\
\hline France & Sweden & Cuba & Singapore \\
\hline Germany & Switzerland & Czech Republic & Slovak Republic \\
\hline Hungary & Syria & Denmark & Spain \\
\hline India & Taiwan & Egypt & Sri Lanka \\
\hline Italy & Thailand & Finland & Sudan \\
\hline Japan & Tunisia & France & Suriname \\
\hline Jordan & Turkey & Germany & Sweden \\
\hline Kuwait & Ukraine & Hungary & Switzerland \\
\hline Luxembourg & Uni Arab Emirates & India & Syria \\
\hline Malaysia & United Kingdom & Italy & Thailand \\
\hline Mauritius & USA & Jamaica & Tunisia \\
\hline Mongolia & Uzbekistan & Jordan & Turkmenistan \\
\hline Netherlands & Venezuela & North Korea & Turkey \\
\hline New Zealand & Vietnam & South Korea & Ukraine \\
\hline Norway & & Kyrgyzstan & United Kingdom \\
\hline Pakistan & & Laos & Uzbekistan \\
\hline Philippines & & Malaysia & Vietnam \\
\hline Poland & & Morocco & Yemen \\
\hline Romania & & Maurítius & Zimbabwe \\
\hline Saudi Arabia & & Mongolia & \\
\hline
\end{tabular}

Sounce: see Table 2. 